\title{
Suspensão da execução de medidas judiciais deferidas para a tutela de interesses ambientais
}

\author{
SUSPENSION OF THE EXECUTION OF LEGAL \\ PROCEEDINGS DEFERRED TO SAFEGUARD \\ ENVIRONMENTAL INTERESTS
}

\author{
Luiz Fernando Bellinetti* \\ José Mauro Luizão**
}

Resumo: O instituto denominado Suspensão de Segurança, que permite suspender os efeitos de decisões judiciais deferidas contra o Poder Público, demanda adequação no que se refere à sua aplicação para suspender medidas deferidas para a tutela de interesses ambientais. A sua adequação aos princípios da inafastabilidade da jurisdição, da efetividade da tutela jurisdicional e do desenvolvimento sustentável pode ser procedida mediante a realização, no processo de suspensão, da ponderação entre o interesse ambiental e a ameaça de lesão ao interesse do Poder Público, com vistas a determinar, no caso concreto, qual deles deve prevalecer.

Palavras-Chave: Suspensão de segurança. Ordem econômica. Meio ambiente. Ponderação.

Abstract: The institute called Suspension of Writ of Mandamus, which enables the suspension of the effects of judicial decisions that may bring about damages to public interests, demand adequacy of its current conformation for the withdrawal of the effectiveness of measures deferred in civil action on environmental issues. Its suitability to the principles of nonobviation and effectiveness of judicial safeguard and the principle of sustainable development may be achieved, on the suspension process, by balancing between the environmental interests and the public interests, objecting to determinate, in each case, which interest must prevail.

Keywords: Suspension of Writ of Mandamus. Economic Order. Environment. Balancing. 


\section{INTRODUÇÃO}

No quadro atual da ordem jurídica brasileira, embora a preservação ambiental e a ordem econômica constituam duas vertentes do princípio do desenvolvimento sustentável, a tutela do meio ambiente encontra-se substancialmente restringida em face da utilização do expediente denominado suspensão de segurança ${ }^{1}$, instituto que tem por finalidade retirar a eficácia de decisões judiciais não transitadas em julgado e que representem ameaça de lesão à ordem, à saúde, à segurança e à economia públicas.

A justificativa da suspensão de segurança, que se sobrepõe aos meios recursais de que dispõe o Poder Público, é a necessidade de um mecanismo eficiente para suspender decisões que acarretem prejuízos aos interesses públicos, como o impedimento ou a postergação de realização de obras e serviços.

Prevalece nos tribunais o entendimento de que o mérito do pedido de suspensão se restringe à demonstração da ameaça ao interesse público, ou seja, à ordem, à saúde, à segurança e à economia públicas, vedada a apreciação sobre o interesse tutelado pela decisão que se pretende suspender. Em consequência, caracterizada a ameaça a algum desses interesses públicos, a execução da decisão judicial concedida contra o Poder Público poderá ser suspensa, ainda que tenha sido prolatada em perfeita consonância com as normas do direito, que seja reputada justa e que espelhe fielmente a realidade dos fatos.

A impossibilidade da apreciação das razões que fundamentaram a decisão concedida contra o Poder Público, com vistas a verificar se deveria de fato ser ela suspensa, caracteriza violação ao princípio da inafastabilidade da jurisdição e da efetividade da tutela jursidicional.

A suspensão de segurança é reputada em conformidade com a Constituição, no entanto, com fundamento no princípio da supremacia do interesse público, justificativa que decorre da origem do instituto, vinculada ao mandado de segurança, ação que se destina a tutelar interesses preponderantemente individuais.

Entretanto, a partir da Lei ${ }^{\circ} 7.347 / 1985$, o instituto passou a ser utilizado também para suspender decisões em ações coletivas, nas quais se tutelam interesses igualmente públicos, como a preservação ambiental. Por conseguinte,

\footnotetext{
${ }^{1}$ Criado pela Lei $\mathrm{n}^{\circ}$ 191/1936 (art. 13), o instituto é regido atualmente pelas Leis ${ }^{\circ}$ 8.437/1990 (art. $4^{\circ}$ ), 8.038/1990 (art. 25) e 12.016/2009 (art. 15). Embora a denominação suspensão de segurança não se afigure adequada para designar as suspensões de execução de medidas judiciais deferidas em ações diversas do mandado de segurança, será ela adotada nesse trabalho em razão de seu uso corrente.
}

SCIENTIAIURIS, Londrina, v.18,n.1,p.91-114,jul.2014 | DOI: 10.5433/2178-8189.2014v18n1p91 
o fundamento da supremacia do interesse público deve ser relativizado como fundamento para se suspender decisões dessa espécie.

Fundamenta-se o instituto ainda na precariedade da decisão suspensa, porque, em regra, se trataria de decisão amparada em cognição não exauriente. Conjuga-se esse fundamento com o da temporariedade da suspensão, porque a medida suspensiva somente vigora até o trânsito em julgado da ação principal.

Esses fundamentos deixam de considerar que a suspensão de segurança pode atualmente atingir todas as espécies de provimentos judiciais concedidos contra o Poder Público, inclusive sentenças e acórdãos de tribunais, proferidos após cognição exauriente. Ademais, a legislação vigente prevê a duração da medida suspensiva até o trânsito em julgado da ação principal, de sorte que a suspensão prolongada da execução da decisão pode esvaziar completamente a sua utilidade.

Por conseguinte, a suspensão da segurança merece ainda melhor reflexão acerca de alguns pontos não suficientemente apreciados, especialmente no que se refere ao seu uso nas ações coletivas.

$\mathrm{O}$ artigo faz um recorte temático, tratando especialmente da suspensão, com fundamento na ameaça à ordem econômica, da execução de decisões judiciais deferidas em ação civil pública para tutelar interesse ambiental.

Considerando que se tratam de interesses que se imbricam e conflitam, conferindo substância ao princípio do desenvolvimento sustentável, postulase a necessidade de se apreciar, no processo de suspensão, a magnitude e a relevância da lesão ao interesse ambiental reconhecidas na medida deferida contra o Poder Público, em contraste com a ameaça à ordem econômica. Postula-se, por conseguinte, o emprego da técnica da ponderação, método que suscita controvérsia acerca da legitimidade democrática do Judiciário.

\section{DESCONFORMIDADE DA SUSPENSÃO DE SEGURANÇA COM A CONSTITUIÇÃO}

A atual conformação da suspensão de segurança, caracterizada pelo entendimento de que o mérito do pedido se restringe à verificação da ocorrência da ameaça ao interesse público, viola os princípios constitucionais da inafastabilidade da jurisdição e da efetividade da tutela jurisdicional, bem como nega valor ao direito fundamental ao desenvolvimento sustentável.

A ordem constitucional brasileira assegura que a lei não excluirá da apreciação do Judiciário lesão ou ameaça de direito, preceito fundamental do 
Estado de Direito. É assim atribuída ao Judiciário a tarefa de defender os direitos ameaçados, "essência da sua função", o que implica definir o conteúdo dos direitos fundamentais albergados pela Constituição. Dessa vinculação do Judiciário aos direitos fundamentais decorrem a prerrogativa de controlar os atos dos demais Poderes e o dever de conferir a tais direitos a máxima eficácia possível e recusar a aplicação de preceitos que não os respeitem (MENDES, 2012, p. 173).

De certa maneira indissociável ao princípio da inafastabilidade do controle do Poder Judiciário, está o da efetividade da tutela jurisdicional.

$\mathrm{O}$ direito à prestação jurisdicional deve ser entendido como direito aos meios executivos necessários, suficientes para dar efetividade ao direito material eventualmente reconhecido, o que implica a tutela jurisdicional tempestiva e, em alguns casos, preventiva (MARINONI, 2010, p. 139-143). A efetividade da tutela jurisdicional não se coaduna com decisões que tornem insuficientes ou inúteis as medidas judiciais, porque insuscetíveis de proporcionar a fruição do direito a quem efetivamente o possui (CINTRA, DINAMARCO e GRINOVER, 2008, p. 39-41).

A suspensão de segurança, considerada a restrição da análise do mérito do pedido à existência da grave ameaça à ordem, à saúde, à segurança e à economia, viola os princípios da inafastabilidade da jurisdição e da efetividade da tutela jurisidicional, ao menos no que se refere à suspensão de decisões destinadas à proteção de interesses que demandam tutela de urgência, como o ambiental.

Não afastam essas conclusões todos os fundamentos de justificação da suspensão de segurança². Não se ignora que o fundamento do instituto é a supremacia do interesse público, que o sacrifício do interesse tutelado pela decisão cujos efeitos foram suspensos somente se verifica enquanto não se tem a certeza definitiva sobre o direito afirmado, que a decisão prolatada contra o Poder Público pode ter sido concedida em juízo de mera verossimilhança e que não se retira a validade da decisão, mas apenas se supende temporariamente seus efeitos.

Essas constatações não afastam a conclusão de que a tutela jurisdicional relativa ao interesse ambiental, uma vez suspensa, está provavelmente fadada

2 Sobre os fundamentos de validade da suspensão de segurança, confira-se os entendimentos de Figueiredo (1997, p. 150-164), Pereira (2003, p. 299-304), Bueno (2008, 243-246), Rodrigues (2010, p. 118-126), Venturi (2010, p. 29-34), Scartezini (2010, p. 62-69) e Rocha (2012, p. 67$95)$.

SCIENTIAIURIS, Londrina, v.18,n.1,p.91-114,jul.2014 | DOI: 10.5433/2178-8189.2014v18n1p91 
à inefetividade, em razão da urgência que essa espécie de tutela requer e porque o escopo fundamental da tutela do meio ambiente é a prevenção do dano.

Vedar ao autor da ação civil pública a possibilidade de que o julgador considere as suas razões, com a finalidade de avaliar se, no caso concreto, deve prevalecer o interesse ambiental implica retirar toda a eficácia da indispensável tutela de urgência. Afirmar que o interesse ambiental será tutelado na ação principal é desconhecimento da realidade ou apego a um formalismo insustentável sob qualquer dos pressupostos que informam o processo e a Jurisdição.

Considerando a demorada instrução da ação civil pública e a possibilidade de apelação e de interposição de recursos especial e extraordinário, uma medida concedida para tutelar o meio ambiente pode permanecer sem eficácia por anos. Não é assim incomum que a decisão judicial definitiva consista em apenas respaldar a constatação do fato consumado. Via de consequência, a degradação ambiental eventualmente reconhecida na decisão definitiva não poderá ser evitada ou ter sua reparação específica, objetivos que se impõe como dever à função jurisdicional ${ }^{3}$.

Insuscetível de tutela jurisdicional condizente com a usual urgência que se revela nos casos concretos, está desprovida de efetividade a previsão constitucional de que o meio ambiente ecologicamente equilibrado deve ser preservado e defendido pelo Estado e pela coletividade. Esta frustração da tutela ao interesse ambiental por vezes ocorre mesmo quando arguida pelo Poder Público, como razão para suspender os efeitos dessa tutela, lesão à ordem econômica que se traduz em interesse meramente patrimonial, interesse secundário, portanto ${ }^{4}$.

\footnotetext{
3 Sobre os efeitos da atual conformação da suspensão de segurança na retirada da eficácia da prestação jurisdicional relativamente à tutela ambiental, é elucidativo o resultado das ações civis públicas $\mathrm{n}^{\circ}$ 1999.70.01.007514-6 e 2006.70.01.004036-9, ajuizadas para tutelar interesse ambiental violado pela construção da Usina Hidrelética de Mauá, no Paraná (informações disponíveis nas páginas da internet da Justiça Federal do Paraná (www.jfpr.jus.br), do Tribunal Regional Federal da 4 a Região (http://www2.trf4.jus.br) e do Superior Tribunal de Justiça (http://www.stj.jus.br). Embora deferidas tutelas protetivas do interesse ambiental, essas decisões não tiveram nenhuma efetividade, em razão de uma suspensão de eficácia de uma antecipação de tutela deferida em janeiro de 2006 por uma decisão do Presidente do Tribunal Regional Federal da $4^{\mathrm{a}}$ Região no Pedido de Suspensão de Segurança de Liminar $n^{\circ}$ 2005.04.01.056295-1/PR. Inaugurada a Usina no início de 2013, algumas decisões, embora reconhecendo a procedência dos pedidos, limitaram-se a constatar a sua inutilidade em razão do fato consumado.

${ }^{4}$ Necessárias as ressalvas de que o interesse secundário não é desimportante, porque os recursos financeiros destinam-se à realização do interesse público primário, ao passo em que que a realização do interesse público primário pode consumar-se com a própria satisfação de determinados interesses dos indivíduos (BARROSO, 2013, p. 93).
}

SCIENTIAIURIS, Londrina, v.18,n.1,p.91-114,jul.2014 | DOI: 10.5433/2178-8189.2014v18n1p91 
Não se ignora que o ordenamento jurídico contempla outras hipóteses de limitação horizontal do âmbito de apreciação do mérito, como na desapropriação. Trata-se, todavia, de interesse patrimonial passível de satisfação pecuniária, enquanto o interesse ambiental, uma vez violado, não pode ser recomposto.

Em tema de direito ambiental, a resolução em perdas e danos é a negação da prestação jurisdicional e representa o insucesso do ordenamento jurídico em dar cumprimento a um dos mais relevantes princípios constitucionais. Inadmissível que se reconheça constitucionalmente um direito, mas se retire a perspectiva da sua fruição (PEREIRA, 2003, p. 299-303). Trata-se, por via transversa, de vedar o acesso à Jurisdição ou de lhe retirar a efetividade.

A suspensão de segurança, na sua atual conformação, leva ainda à negação do direito fundamental ao desenvolvimento sustentável.

Definido no Relatório Brundtland, elaborado em 1987 pela Comissão Mundial Sobre Meio Ambiente e Desenvolvimento instalada pela ONU, como "aquele que atende às necessidades do presente sem comprometer a possibilidade de as gerações futuras atenderem às suas necessidades", o princípio do desenvolvimento sustentável engloba os aspectos econômico, social e ambiental, que constituem os pilares que o integram e lhe dão suporte e que foram contemplados pela Constituição de 1988 por meio da confluência do objetivo de erradicar a pobreza e reduzir as desigualdades sociais (art. $3^{\circ}$, I e III), do estabelecimento de uma ordem econômica sustentável (art. 170, VI) e do dever de tutela ecológica atribuído ao Estado e à sociedade (art. 225) (SARLET, FENSTERSEIFER, 2012, p. 45).

O meio ambiente e a ordem econômica receberam assim tratamento constitucional que os tornam interdependentes e indissociáveis.

A preservação ambiental mereceu especial proteção na Constituição, que erigiu o meio ambiente a bem comum de uso comum do povo, essencial à sadia qualidade de vida, e atribuiu ao Estado e à coletividade o dever de preservá-lo. A proteção ao ambiente, no entanto, tem caráter antropocêntrico, porque sua finalidade é preservar a vida e a dignidade humanas (MACHADO, 2009, p. 129).

Paralelamente, a Constituição assegura direitos sociais, entre os quais a educação, a saúde, a moradia, a previdência e a assistência sociais, direitos que igualmente remetem à finalidade de garantia da qualidade da vida e da dignidade da pessoa humana. 
O atendimento a essas necessidades sociais pressupõe o desenvolvimento econômico, de sorte que a finalidade de assegurar a todos uma existência digna, uma sadia qualidade de vida, conforme os ditames da justiça social, tem por sustentáculo a atividade econômica e o proveito dela decorrente (BASTOS, 2003, p. 127-129). Logo, a política econômica do Estado é determinante para a consecução dos princípios da ordem econômica, afigurando-se essencial para fornecer as condições estruturais necessárias para o desenvolvimento. Impensável a consecução do escopo de assegurar a todos uma existência digna sem a realização de empreendimentos estatais, como estradas, portos e hidrelétricas.

Afirma-se, por conseguinte, que a qualidade de vida, como finalidade da ordem econômica, deve coincidir com a qualidade de vida postulada pela preservação ambiental. Inadmitida, pois, a concepção da qualidade de vida como mero "conjunto de comodidades materiais, nem como a tradução do ideal da volta à natureza, expressando uma reação e indiscriminado desprezo a toda elaboração técnica e industrial” (DERANI, 2008, p. 57-58). Não se veda a exploração econômica de recursos naturais, nem se almeja a proteção ambiental com pretensão de intangibilidade, mas a manutenção do ambiente dentro de parâmetros que lhe preservem a condição de ecologicamente equilibrado (TAVARES, 2011, p. 188).

Completa-se assim o círculo de imbricação entre a preservação ambiental e a ordem econômica, ambas com o escopo de proporcionar a todos uma existência digna, de sorte que a ação em benefício da natureza pode levar a uma melhor qualidade de vida para a atual e futuras gerações (BASTOS, 2003, p. 156), ao mesmo tempo em que a defesa do meio ambiente é princípio da ordem econômica.

Por conseguinte, as soluções jurídicas de questões que envolvam interesses ambientais e econômicos devem ser orientadas pelo pressuposto do objetivo da compatibilização e harmonização desses interesses. Ao atribuir prévia e abstrata prevalência ao aspecto econômico, impedido a tutela efetiva do meio ambiente, a suspensão de segurança caracteriza negação a esse equilíbrio preconizado pelo princípio do desenvolvimento sustentável.

Por fim, a atual conformação da suspensão de segurança, considerada a perspectiva de que as medidas deferidas contra o Poder Público para a tutela dos interesses ambientais poderão ter sua eficácia inteiramente suprimida, pode ainda levar o Estado a negligenciar o seu dever de zelar pela preservação ambiental, além de induzir ao manejo inadequado da ação civil pública. 
Ao decidir pela realização de empreendimentos econômicos, o Poder Público pode descurar dos impactos ambientais, bem como dos sociais, porque sabe que sua decisão de natureza política não será eficientemente submetida ao controle jurisdicional, nos aspectos da competência, legalidade e formalidade. Essa indução à desídia pode se revelar na própria definição da estratégica de desenvolvimento, com a inobservância de critérios adequados de zoneamento econômico. Mais frequentemente, leva à elaboração de estudos de impactos ambientais deficientes, causa mais comum do ajuizamento de ações civis públicas em matéria ambiental.

Ao mesmo tempo, a perspectiva da inefividade da decisão protetiva do interese ambiental pode levar os legitimados ativos e o magistrado a descurar da necessária cautela nos atos de postular e decidir a ação civil pública.

\section{ALTERNATIVAS DE ADEQUAÇÃO DA SUSPENSÃO DE SEGURANÇA}

Ressalva a declaração da inconstitucionalidade total e absoluta do pedido de suspensão de segurança, nos termos do que postulam Bueno (2008, p. 243245) e Ferraz (2006, p. 359), a compatibilização do instituto com a Constituição, considerado o escopo fundamental da efetividade da prestação jurisdicional, com vistas à realização do princípio do desenvolvimento sustentável, demanda uma substancial alteração na sua atual conformação.

As alternativas de compatibilização consistem na supressão da ultratividade da decisão que defere a medida suspensiva, na exigência de que a decisão do pedido de suspensão seja procedida mediante critérios jurídicos e, especialmente, na declaração definitiva, pela via legal, jurisprudencial e doutrinária, da possibilidade de se invocar, no processo de suspensão, a prevalência do interesse ambiental tutelado pela decisão contrária ao Poder Público. Paralelamente, a atual quadra constitucional justifica a própria inclusão da preservação ambiental como um dos interesses que fundamentam a suspensão da segurança.

\subsection{Eliminação da Ultratividade da Decisão Suspensiva}

A regra da ultratividade da decisão que suspende a eficácia de medidas judiciais concedidas contra o Poder Público é particularmente inadequada em relação às ações civis públicas destinadas à tutela ambiental. 
A ultratividade da decisão suspensiva é justificada pela assertiva de que superveniência da sentença de procedência não tem influência no pedido de suspensão, porque distintos são os fundamentos, pressupostos e objetivos de cada ação. Assim, se os presupostos da suspensão estavam presentes por ocasião do deferimento da liminar, estariam também presentes quando proferidos a sentença ou o acórdão que confirmam o teor da medida de urgência (VENTURI, 2010, p. 244). Exatamente por essa razão o STF editou a Súmula $n^{\circ} 626$, estabelecendo que a suspensão terá vigor até o trânsito em julgado da decisão definitiva, "desde que o objeto da liminar deferida coincida, total ou parcialmente, com o da impetração".

Entretanto, especialmente no que tange à ação civil pública, esse raciocínio deixa de considerar que a liminar é concedida em cognição sumária e a sentença após dilação probatória exauriente (SCARTEZINI, 2010, p. 74-75). Por conseguinte, a ampla dilação probatória realizada infirma os fundamentos de constitucionalidade da suspensão de segurança, caracterizados pela temporariedade da decisão suspensiva e pela precariedade da decisão que se pretende suspender. $O$ grau crescente de certeza que se obtém da sentença que confirma a liminar ou a tutela antecipada não pode ser desconsiderado. Com mais razão ainda, não pode ser desconsiderada a certeza, especialmente em matéria de fato, decorrente do acórdão do Tribunal que confirma a sentença de primeiro grau, porque esse aspecto é insuscetível de apreciação em eventuais recursos especial ou extraordinário.

Acrescente-se que a finalidade precípua das tutelas de urgência é particularmente relevante nas ações para tutela de interesse ambiental.

Essas peculiaridades levam à inaplicablidade da ultratividade da suspensão de segurança a essas ações. Esvaziado o conteúdo das tutelas de urgência, restará inefetiva a tutela jurisdicional do meio ambiente, ferindo os princípios consitucionais que orientam a atuação do Estado para o desenvolvimento sustentável. Por conseguinte, ainda que a sentença mantenha integralmente a liminar ou a antecipação da tutela, é necessária a apresentação de novo pedido de suspensão.

A eliminação da ultratividade da decisão que suspende a execução da tutela concedida contra o Poder Público, além de robustecer os fundamentos de validade da suspensão de segurança, caracterizados pela temporariedade da suspensão e pela precariedade da tutela concedida na 
ação principal, restringiria o sacrifício do interesse ambiental contraposto ao interesse do Poder Público.

Entretanto, considerando que ação civil pública admite ampla dilação probatória, a possibilidade da antecipação da tutela, provida de plena eficácia, é determinante para a proteção do interesse ambiental. Por sua vez, a tutela concedida na sentença de primeiro grau também pode revelar-se inteiramente esvaziada se sua eficácia estiver condicionada à confirmação da decisão do recurso ao tribunal e mesmo ao desfecho dos recursos especial ou extraordinário.

Via de consequência, a decisão judicial na ação civil pública, ainda que julgue procedente o pedido, pode ter sua eficácia restaurada somente quando o dano ao meio ambiente já tiver sido consolidado e for irreparável. Trata-se de situação que não se amolda à estatura do interesse ambiental conferida pelo artigo 225 da Constituição, nem tampouco às previsões do artigo 461 do Código de Processo Civil e do artigo 84 do Código de Defesa do Consumidor, que estipulam que a prestação jurisdicional deve privilegiar a tutela específica.

Nesse quadro, embora a eliminação da ultratividade da decisão suspensiva tenha significativo efeito para reduzir o sacrifício do interesse ambiental, não é suficiente para eliminar a distorção provocada pelo instituto, que reside essencialmente na impossibilidade de se apreciar, no âmbito do pedido de suspensão, qual interesse deve prevalecer.

\subsection{Decisão do Pedido de Suspensão Mediante Critérios Jurídicos}

O exame dos repertórios de jurisprudência revela uma tendência dos tribunais de conferir à decisão do pedido de suspensão de segurança a natureza de ato político-administrativo 5 .

Trata-se de concepção desprovida de fundamento, porque o ato que suspende a execução de uma decisão de outro órgão do Judiciário é inquestionavelmente jurisdicional e, nesta qualidade, está adstrito aos princípios que informam a jurisdição e o processo, especialmente o contraditório, a ampla defesa e a motivação das decisões. Como refere Rodrigues (2010, p. 92-94), aderindo à doutrina nacional predominante, é inaceitável a concepção de que a suspensão de segurança é revestida de natureza de medida administrativa, praticada no exercício de poder discricionário destinado a aplicar o princípio da

5 Da atribuição dessa natureza decorre a usual inobservância dos princípios constitucionais processuais da ampla defesa, do contraditório, da motivação das decisões e da intervenção do Ministério Público no procedimento dos pedidos de suspensão de segurança.

SCIENTIAIURIS, Londrina, v.18, n.1,p.91-114,jul.2014 | DOI: 10.5433/2178-8189.2014v18n1p91 
supremacia do interesse público. Ainda que se admita que os pressupostos da suspensão tenham inspiração política, "a decisão pertinente é eminentemente jurisdicional" (FERRAZ, 2006, p. 369). O pedido de suspensão não pode assim "significar mero trespasse de competências exclusivamente administrativas aos presidentes dos tribunais que não se podem valer do instituto em nome do prevalecimento de políticas públicas ou juízos de conveniência e oportunidade administrativas" (BUENO, 2008, p. 245).

Destoa da ordem democrática constitucional, que se logrou construir a partir de 1988, constatar que uma decisão proferida por um órgão jurisdicional está sendo prolatada em juízo de conveniência e oportunidade, abstraindo-se de critérios jurídicos. A função do Judiciário é atuar na condição de terceiro imparcial em relação aos interesses em disputa, de sorte que o único interesse que o pode mover, como afirma Silva (2011, p. 68-69), é o de respeito à ordem constitucional, ao contrário do Administrador que age para que determinadas finalidades sejam alcançadas.

Ao decidir um pedido de suspensão de segurança por critérios de conveniência e oportunidade, o julgador renuncia ao seu dever constitucional de atuar, com imparcialidade, para solucionar o conflito de interesses entre a Administração e o indivíduo. No caso de ação relativa a matéria ambiental, renuncia ao seu dever de solucionar o conflito entre dois interesses igualmente públicos e relevantes. Essa renúncia caracteriza subversão da natureza contramajoritária do Poder Judiciário nos Estados Democráticos de Direito e que se destina à proteção dos direitos fundamentais.

De qualquer forma, ainda que absolutamente indispensável que as decisões dos pedidos de suspensão de segurança sejam procedidas mediante critérios jurídicos, essa adequação representaria solução apenas parcial no escopo de conferir efetividade à prestação jurisdicional relativa os interesses ambientais. Vedada a consideração sobre a possibilidade da prevalência do interesse ambiental, remanesceria o interesse ambiental desprovido de tutela efetiva.

\subsection{Revisão do Mérito do Pedido de Suspensão}

A adequação da suspensão de segurança aos preceitos constituicionais pode ser alcançada pela revisão do âmbito de apreciação do mérito do pedido.

Adotada a premissa de que os interesses transindividuais tutelados na ação civil pública, especialmente o ambiental, são públicos e relevantes, à semelhança dos interesses tuteláveis pela suspensão de segurança, a solução 
que se apresenta consentânea com os preceitos constitucionais é permitir que se realize, no âmbito do pedido de suspensão, a análise acerca de qual desses interesse deve prevalecer no caso concreto. Como postula Bueno (2008, p. 244-245), trata-se de harmonizar a suspensão de segurança com a Constituição mediante a constatação, no caso concreto, de que efetivamente se configura hipótese de manifestação do princípio basilar da supremacia do interesse público, caso em que a liminar que favorece um particular deve ceder espaço a um interesse maior e mais amplo.

Em outros termos, a alternativa implica condicionar o deferimento do pedido de suspensão de segurança à demonstração de que a ameaça à ordem, à segurança, à saúde e à economia públicas, além de grave, não é aceitável quando cotejada com a lesão decorrente da suspensão da execução da medida deferida contra o Poder Público ${ }^{6}$.

\subsubsection{Inclusão do interesse ambiental como pressuposto da suspensão de segurança}

$\mathrm{Na}$ ordem constitucional vigente, em que o ambiente ecologicamente equilibrado foi erigido a direito fundamental, incumbindo ao Estado e à sociedade o dever de preservá-lo para a presente e futuras gerações, justifica-se a sua inclusão como um dos interesses tutelados pela suspensão da segurança, ao lado da ordem, da segurança, da saúde e da economia públicas.

O meio ambiente ecologicamente equilibrado foi elevado à condição de bem de uso comum do povo e essencial à sadia qualidade de vida, revelando que a proteção ambiental tem fundamento no interesse coletivo ou social, fundamental para a consecução de um objetivo de bem-estar comum (DERANI, 2008, p. 247).

Justifica-se, portanto, a inclusão da preservação ambiental como um dos interesses que fundamentam o pedido de suspensão de segurança, como instrumento para dar cumprimento ao dever estatal estipulado no caput do artigo 225 da Constituição Federal, de defender e preservar o meio ambiente para as presente e futuras gerações.

\footnotetext{
${ }^{6}$ Para as finalidades desse trabalho, a análise se restringe à tutela do interesse ambiental, contraposto à ordem econômica, situação comum em grandes empreendimentos estatais, como estradas, portos e usinas hidrelétricas. Todavia, a análise parece guardar razoável pertinência com outros interesses transindividuais e mesmo em relação a alguns interesses privados que se insiram na qualificação de direitos fundamentais.
}

SCIENTIAIURIS, Londrina, v.18,n.1,p.91-114,jul.2014 | DOI: 10.5433/2178-8189.2014v18n1p91 


\subsubsection{Ponderação dos interesses ambiental e econômico no pedido de suspensão de segurança}

O direito ao desenvolvimento sustentável se insere em um processo que deve ser construído na medida do enfrentamento dos conflitos entre interesses ambientais, econômicos e sociais.

A solução desejável desses conflitos deve ser procedida na instância administrativa, considerada a ampla possibilidade de atuação e intervenção do Poder Público na ordem econômica. Paralelamente é atribuída ao próprio Estado, ao lado da sociedade, a função primordial de defender e preservar o meio ambiente ecologicamente equilibrado, para tanto dispondo de meios de planejamento, de fiscalização e de imposição de sanções, inclusive de natureza penal. Ademais, a compatibilização dos interesses sociais, econômicos e ambientais não é senão a finalidade essencial dos Estudos de Impactos Ambientais, que cabe ao Poder Público exigir para instalação de obra ou atividade potencialmente causadora de degradação ambiental, nos termos do inciso IV do artigo 225 da Constituição.

No entanto, quando frustrada a compatibilização na via administrativa e judicializado o conflito entre interesses ambientais e econômicos, o ordenamento jurídico contempla meios para dirimi-lo, acrescentando aos métodos tradicionais de interpretação alguns instrumentos especialmente concebidos para estabelecer parâmetros relativamente constantes e que reduzam, o quanto possível, a subjetividade do intérprete. Desses critérios de solução de conflitos, o de mais larga aplicação, e também o de mais acirrada controvérsia, é o da ponderação.

Embora não se trate de solução isenta de críticas ou de dificuldades de aplicação nos casos concretos, a ponderação não é técnica desconhecida do direito brasileiro, afigurando-se de larga aplicação na prática jurisdicional.

A ponderação, definida como "técnica jurídica de solução de conflitos normativos que envolvem valores ou opções políticas em tensão, insuperáveis pelas formas hermenêuticas tradicionais" (BARCELOS, 2005, p. 35), ingressou na atual hermenêutica como exigência das modernas constituições, impregnadas de princípios dotados de plena normatividade e que cumprem a função de lhe conferir abertura e a plasticidade (HESSE, 1992, p. 17-20). Inevitável, por conseguinte, a atualização dos métodos hermenêuticos para possibilitar uma interpretação constitucional consentânea com essa nova configuração. Esses critérios, embora se revelem permeáveis à subjetividade, como qualquer outro

SCIENTIAIURIS, Londrina, v.18, n.1,p.91-114,jul.2014 | DOI: 10.5433/2178-8189.2014v18n1p91 
método (SILVA, 2010. p. 146-148), operam como "balizas para a interpretação das normas constitucionais, com o objetivo de conferir maior teor de racionalidade à tarefa, reduzindo o espaço para pragmatismos exacerbados" (MENDES, 2012, p. 104).

Entre as críticas que se destina à ponderação, em face de lhe faltarem critérios racionais de decidibilidade, afirma-se que é uma técnica metodologicamente inconsistente e que permite excessivo subjetivismo, ensejando arbitrariedade e voluntarismo (BARCELOS, 2005, p. 50-55) ${ }^{7}$.

Para Barroso (2013, p. 362-365), embora a ponderação preveja a "atribuição de pesos diversos aos fatores relevantes de determinada situação, não fornece referências materiais ou axiológicas para a valoração a ser feita". Entretanto, como anota o autor, "a ponderação ingressou no universo da interpretação constitucional como uma necessidade, antes que como uma opção filosófica ou ideológica", razão pela qual o que se afigura necessário é desenvolver "alguns elementos de segurança, alguns vetores interpretativos".

Assim, a doutrina indica a conjugação da ponderação com outros critérios interpretativos, especialmente a proporcionalidade, a concordância prática, a razoabilidade e a proibição de excesso ou proteção do núcleo essencial ${ }^{8}$.

Noutro aspecto, o exercício da ponderação e a definição da preponderância dos direitos fundamentais suscitam alegação de ausência de legitimidade do Poder Judiciário em face de sua atuação contramajoritária. Ao contrário dos membros dos demais Poderes, os magistrados não são eleitos por voto popular. Logo, a decisão fundada em valores extraídos de princípios de conteúdo semântico e de rarefeita determinação, que não foi objeto de expressa deliberação dos representantes eleitos pelo povo, pode ser reputada antidemocrática9 .

\footnotetext{
7 No que se refere ao subjetivismo da ponderação, oportuna a ressalva de Silva (2010, p. 146-148), de que não se revela possível estabelecer uma racionalidade que exclua completamente a subjetividade dos métodos de interpretação, inclusive a subsunção. Além do mais, um dos postulados do póspositivismo, que alberga a ponderação como um dos critérios hermenêuticos prevalentes, é precisamente a redução da subjetividade do intérprete. Como refere Sarmento (2010, p. 59-60), a teoria moderna dos princípios se insurge precisamente contra a ideia da subjetividade do intérprete nos casos difíceis, e "vai insistir na necessidade de não deixar os atos de aplicação do direito fora do âmbito da argumentação racional e do controle social. Neste sentido, ela se casa com o processo de revalorização, no universo jurídico, da racionalidade prática, importando na adoção de uma compreensão muito mais rica da hermenêutica jurídica".

8 Sobre esses critérios, confira-se Mendes (2012, p. 104-110 e 241-266) e Ávila (2012, p. 166-196).

9 No que se refere ao emprego da técnica da ponderação e o embate entre constitucionalismo e democracia, aspecto central da discussão acerca da legitimidade democrática do Judiciário, confirase as considerações de Branco (2009, p. 57-145).
}

SCIENTIAIURIS, Londrina, v.18,n.1,p.91-114,jul.2014 | DOI: 10.5433/2178-8189.2014v18n1p91 
Entretanto, como lembra Sarmento (2009, p. 122-139), a jurisdição constitucional e a exigência da proteção dos direitos fundamentais estão previstos na própria Constituição, razão pela qual o debate relevante não se cinge à sua possibilidade, mas à forma do seu exercício. Admite-se, ademais, que a democracia não se esgota na vontade da maioria, pressupondo igualmente o respeito à garantia de direitos básicos, a participação igualitária do cidadão na esfera pública e alguma forma de proteção às minorias. A questão, portanto, é de dosagem. A permissão aos juízes para a imposição de limites às decisões das maiorias somente pode ser reputada antidemocrática se caracterizar demasiado cerceamento da possibilidade de autogoverno atribuída ao povo. No mesmo sentido, para Ávila (2009, p. 196), em vez da insindicabilidade dessas decisões, é preciso verificar em que medida essas competências são exercidas, o que demanda encontrar-se critérios que "aumentem e que restrinjam o controle material a ser exercido pelo Poder Judiciário".

Necessário, portanto, consolidar-se a construção ou o aprimoramento de paradigmas adequados à nova hermenêutica constitucional, bem como de melhor compreender os limites da atuação contramajoritária do Poder Judiciário ${ }^{10}$. Afirma-se, por conseguinte, que o emprego da ponderação, ausente a referibilidade direta da decisão a evidentes enunciados normativos, amplia a necessidade da racionalidade e da justificação da decisão judicial (BARCELOS, 2005, p. 41-45).

Consideradas as ressalvas acerca do juízo de ponderação, parece não existir nenhuma característica essencial que distinga a sua utilização nos pedidos de suspensão de segurança daquela procedida em outros institutos processuais.

Embora o pedido de suspensão se trate de procedimento sem dilação probatória e que exige celeridade, essas características não impedem a realização da ponderação das normas que veiculam os interesses contrapostos, como de resto não a impedem nos demais procedimentos sem dilação probatória ou naqueles que exigem celeridade, como nas antecipações de tutela e cautelares.

\footnotetext{
${ }^{10}$ Essencial a compeensão de que a proteção dos direitos fundamentais exige que a realização da ponderação seja procedida no caso em concreto, pelo Judidiário, porque é incompatível com a ordem constitucional a prévia e absoluta restrição de um direito fundamental. Evidentemente o legislador pode e deve exercer um juízo de ponderação ao elaborar as normas abstratas. $\mathrm{O}$ que não se afigura possível é subtrair do Judiciário a possibilidade de realizar a ponderação no caso concreto, com vistas a evitar a supressão de um direito fundamental, nas hipóteses em que a compatibilização de interesses em conflito não se revelou possível na via legislativa.
}

SCIENTIAIURIS, Londrina, v.18,n.1,p.91-114,jul.2014 | DOI: 10.5433/2178-8189.2014v18n1p91 
Igualmente não se pode afirmar que carece o julgador de elementos indispensáveis para a ponderação das normas contrapostas. No que se refere ao interesse ambiental, constitui elemento decisório, no mínimo, a decisão cujos efeitos se pretende suspender, enquanto a demonstração da ameaça ao interesse econômico deve necessariamente ser objeto do pedido de suspensão ${ }^{11}$.

De igual forma, nada parece existir que vede o exercício da ponderação entre interesses ambientais e econômicos.

Considerando que a ordem constitucional não contempla hierarquia ou precedência entre direitos fundamentais, exceto no que se refere à vida e à dignidade humana, valores que estão subjacentes igualmente à ordem econômica e ao direito ao meio ambiente ecologicamente equilibrado, é pressuposto inafastável da solução na via jurisdicional que não se há de atribuir preponderância absoluta ao interesse ambiental ou ao interesse econômico em conflito.

Embora o direito ao meio ambiente ecologicamente equilibrado não esteja expressamente sujeito a limitações constitucionais, a necessidade de sua harmonização com os interesses sociais e econômicos constitui a essência do direito ao desenvolvimento sustentável. A ordem econômica, por sua vez, é composta por uma plêiade de interesses, valores e objetivos que se complementam e autolimitam, inclusive, a preservação ambiental.

Por conseguinte, caracterizado no caso concreto o conflito de direitos fundamentais, como os escopos da preservação ambiental e de consecução de uma ordem econômica consentânea com os valores constitucionais, devese procurar o "balanceamento entre esses postulados", de modo a permitir a tutela urgente do interesse ambiental atingido pelo empreendimento público, ao mesmo tempo em que se busca garantir que a atividade estatal não seja paralisada sem justificativa relevante (CARVALHO FILHO, 2004, p. 379).

Essa exigência de ponderação não é senão a exigência do princípio do desenvolvimento sustentável, que contempla elementos que representam aspirações de realização de valores atinentes aos aspectos ambientais, sociais e econômicos. Trata-se de interesses que não são irrestringíveis, desde que a restrição seja justificável pela necessidade de harmonização com outros interesses igualmente reputados valiosos pela ordem constitucional.

${ }^{11} \mathrm{O}$ que pode ocorrer, é que a decisão não contemple a necessária fundamentação ou delimitação do âmbito de seu comando, de modo a não permitir a decisão no sentido da prevalência do direito ambiental. Em sentido inverso, a fundamentação deficiente do pedido de suspensão pode levar à impossibilidade da prevalência do interesse econômico defendido pelo Poder Público.

SCIENTIAIURIS, Londrina, v.18,n.1,p.91-114,jul.2014 | DOI: 10.5433/2178-8189.2014v18n1p91 
Não há, portanto, razão jurídica que impossibilite a ponderação no âmbito de pedido de suspensão ajuizado, com fundamento na ameaça à economia pública, para retirar a eficácia de medida concedida para tutelar interesse ambiental.

A ausência desse exercício de ponderação caracteriza uma omissão da função jurisdicional de dar proteção aos direitos fundamentais, na medida da possibilidade da sua realização. Em outros termos, embora possa o Judiciário negar a tutela jurisdicional a um determinado interesse por reputálo, no caso concreto, menos valioso que outro que lhe é contraposto, não pode negar essa mesma tutela somente em face da previsão legal abstrata de prevalência desse outro interesse.

Registre-se a negação dessa tutela, especificamente no que se refere à suspensão de segurança, decorre de uma interpretação jurisprudencial e doutrinária inconsistente. Com efeito, mesmo aqueles autores que postulam a restrição do âmbito de apreciação do pedido de suspensão de segurança, consideram que se há de proceder a alguma espécie de ponderação entre os interesses contrapostos ou, ao menos aferir-se a plausibilidade do eventual recurso do Poder Público na ação principal ${ }^{12}$. Outra não é a conclusão no que se refere à Jurisprudência. Como relata Bezerra (2009, p. 217-225), em muitas ocasiões o Supremo Tribunal Federal efetuou a ponderação de normas que veiculam interesses em conflito e concluiu que deveria prevalecer o interesse tutelado pela medida que se pretendia suspender. Outras tantas vezes, concluiu pela prevalência do interesse do Poder Público, mas não deixou de ponderar as razões dessa prevalência.

Essas constatações revelam que a doutrina e a jurisprudência reputam possível o exercício da ponderação no pedido de suspensão de segurança. Os tribunais, ao ponderar as normas em conflito e, por vezes, reconhecer a prevalência do interesse que se pretende suspender, assim procedem sem o reconhecimento da inconstitucionalidade das normas de regência da suspensão de segurança. Trata-se de inequívoco reconhecimento de que a restrição do âmbito de apreciação do mérito do pedido é construção exclusivamente jurisprudencial e doutrinária.

\footnotetext{
${ }^{12}$ Pela admissibilidade do exercício de ponderação, posicionam-se, entre outros, Bezerra (2009, p. 256-262), Rodrigues (2010, p. 124-125), Venturi (2010, p. 159-162, 215-216, 277-279). Admitem a verificação da plausibilidade do recurso do Poder Público Tombini (2009, p. 89-90) e Scartezini (2010, p. 104-105). Rocha (2012, p. 187-196) admite igualmente a verificação da plausibilidade do recurso e a ponderação.
}

SCIENTIAIURIS, Londrina, v.18,n.1,p.91-114,jul.2014 | DOI: 10.5433/2178-8189.2014v18n1p91 


\section{PROPOSTA DE REVISÃO DO PEDIDO DE SUSPENSÃO DE SEGURANÇA}

Com fundamento nas razões expostas, propõe-se a adoção do entendimento de que o deferimento do pedido de suspensão de segurança deve ser condicionado à demonstração de que a ameaça à ordem, à segurança, à saúde e à economia públicas, além de grave, não é aceitável quando cotejada com a lesão decorrente da suspensão da execução da medida judicial deferida contra o Poder Público. Em outros termos, trata-se de harmonizar a suspensão de segurança com a Constituição mediante a demonstração de que, no caso concreto, efetivamente se configura hipótese de manifestação da supremacia do interesse público, caso em que a decisão judicial deve ceder espaço a um interesse maior, que é o da coletividade (BUENO, 2008, p. 244-245). Nada obsta que a supremacia do interesse público - a ordem econômica - seja reconhecida em prejuízo de um interesse igualmente público - o interesse ambiental -, desde que esse reconhecimento seja procedido no caso concreto, mediante a ponderação dos interesses em conflito.

Não se trata, porém, de condicionar o deferimento da suspensão à demonstração de que a tutela judicial que acarreta lesão aos interesses públicos foi concedida mediante erro de julgamento ou de procedimento como postula Bueno $\left(2008\right.$, p. 246) ${ }^{13}$, bem como não se considera inteiramente adequada a solução proposta por Bezerra $(2009$, p. 256), no sentido de que "a integralidade da situação fático-jurídica" seja considerada no julgamento do pedido de suspensão ${ }^{14}$. Por outro lado, a verificação da plausibilidade do recurso facultado ao Poder Público no processo principal, embora se afigure imprescindível, é insuficiente, não suprindo a necessidade da ponderação dos interesses em conflito ${ }^{15}$.

${ }^{13}$ Uma decisão juridicamente correta pode provocar danos graves aos interesses do Poder Público, que podem ser considerados inaceitáveis quando cotejados com o dano ao ambiente.

${ }^{14}$ A solução é juridicamente inaceitável, além de faticamente inviável, considerando as finalidades, pressupostos e o procedimento da suspensão de segurança.

${ }^{15}$ A plausibilidade do recurso é fundamento de muitos dos julgados que admitem a denominada delibação ou cognição superficial ou sumária, raros casos, entretanto, em que o interesse tutelado pelo Poder Público já foi anteriormente tido por manifestamente insubsistente. A solução deixa de considerar situações em que o recurso do Poder Público é plausível, mas a ameaça de dano ao seu interesse não justifica a suspensão da tutela ao interesse ambiental. Em sentido inverso, o recurso do Poder Público pode se revelar de duvidosa plausibilidade, mas a ameaça ao seu interesse é extremamente grave e decorre de medida destinada a tutelar interesse ambiental pouco relevante.

SCIENTIAIURIS, Londrina, v.18,n.1,p.91-114,jul.2014 | DOI: 10.5433/2178-8189.2014v18n1p91 
A proposta consiste, em suma, em dilargar o âmbito de apreciação do mérito do pedido de suspensão de segurança, de modo a permitir a análise sobre a possibilidade da prevalência do interesse ambiental. O âmbito de apreciação do mérito consistiria na análise da gravidade da ameaça ao interesse do Poder Público, considerada ainda a relevância desse interesse, em cotejo com a magnitude e relevância do dano ao interesse ambiental que se pretende evitar. Essa apreciação ampliada do mérito do pedido de suspensão deve ser procedida sem dilação probatória e sem apreciação da juridicidade da decisão que se pretende suspender, possibilitando o imediato pronunciamento judicial acerca da contrastabilidade do interesse ambiental ao econômico, determinando a prevalência de um ou de outro ou a compatibilização de ambos. A celeridade e a eficácia do instituto da suspensão ficariam razoavelmente preservadas, porque não se admitiria dilação probatória. Tampouco implicaria atribuição de poder revisional ao julgador do pedido de suspensão, porque a decisão proferida na ação civil pública, ainda que tenha seus efeitos suspensos, permaneceria hígida, tal como atualmente acontece.

Embora a ponderação dos interesses em conflito no âmbito do pedido de suspensão possa ser procedida como mera interpretação jurisprudencial, independentemente de necessidade da alteração legislativa ou de declaração de inconstitucionalidade de qualquer dispositivo legal, é recomendável a alteração legislativa, inclusive porque a proposta implica a retirada da regra da ultratividade da decisão suspensiva.

A ponderação dos interesses em conflito, com efeito, inviabiliza definitivamente a ultratividade da decisão que defere a suspensão da segurança.

$\mathrm{Na}$ atual conformação do pedido de suspensão, a ultratividade é justificada porque, se os presupostos da suspensão, que são exclusivamente a grave ameaça aos interesses do Poder Público, estavam presentes por ocasião do deferimento da liminar, estariam presumivelmente presentes quando proferida a sentença.

Entretanto, ao se adicionar como requisito da suspensão a necessidade da prevalência do interesse econômico, aferível no caso concreto mediante ponderação com o interesse ambiental, essa imutabilidade dos pressupostos deixa de existir. A sentença, após a dilação probatória, pode reconhecer a possibilidade de dano ambiental em maior ou menor monta que aquele aferido em juízo de verossimilhança, em cognição sumária. De igual forma, o acórdão do Tribunal pode reconhecer a existência do dano ou ameaça em dimensão distinta do que concluiu a sentença. Ademais, postula-se que a dimensão e gravidade do dano ao interesse ambiental sejam extraídas da decisão judicial. 
Logo, esses parâmetros devem ser extraídos da decisão que agregou grau de certeza sobre a decisão anterior.

Por fim, o exercício da ponderação entre os interesses contrapostos no pedido de suspensão reforça a conclusão de que é inadmissível a decisão do pedido de suspensão de segurança mediante critérios de conveniência e oportunidade.

Ainda que se atribua ao juízo de ponderação uma subjetividade que perigosamente faz aproximar a atuação judiciária da atividade legislativa, a atribuição ao julgador do dever de ponderar os interesses contrapostos acrescenta à sua decisão, ou ao menos reforça, duas características que marcam a jurisdição, ou seja, o dever de imparcialidade e a finalidade de atuação da lei. Definitivamente, o exercício de ponderar os interesses, para verificar qual deles deve prevalecer no caso concreto, não pode ser confundido com a função de proteção do interesse do Poder Público, tal como hoje, equivocadamente, se postula. Em verdade, o emprego da técnica da ponderação exacerba a necessidade da fundamentação racional e da justificação da decisão do pedido de suspensão. Via de consequência, a decisão deve necessariamente indicar a vinculação da solução adotada ao ordenamento jurídico, justificando devidamente as suas razões, o que se faz, evidentemente, mediante critérios jurídicos.

\section{CONSIDERAÇÕES FINAIS}

Ainda que os fundamentos de validade da suspensão de segurança devam ser relativizados em relação a medidas deferidas para a tutela do interesse ambiental, não se pode inteiramente descartar a sua prestabilidade como instrumento de proteção a interesses públicos, como a saúde, a ordem, a segurança e a economia, desde que amoldada a sua conformação às exigências constitucionais e desde que realizada a ponderação dos interesses em conflito, com vista a se aferir, na situação concreta, qual interesse deve prevalecer.

Inadmissível que a suspensão de segurança, como qualquer outro instituto processual, contemple a possibilidade de restrição ou supressão de direitos fundamentais, entre eles a preservação ambiental, sem que se permita que a prevalência desses interesses seja invocada no caso em concreto. Não se admite a estipulação em abstrato de direitos fundamentais prevalecentes, exceto no que se refere à vida e à dignidade humana. Todos os demais são restringíveis em face da necessidade de prevalência de outro direito de mesma 
espécie, o que somente se pode proceder no caso concreto, tarefa atribuída ao Poder Judiciário nas ordens constitucionais democráticas.

É esse o ponto em que esbarra a aplicação da atual conformação da suspensão de segurança para retirar a eficácia de decisões concedidas para a tutela de interesses ambientais, em razão de prevalecer nos tribunais o entendimento de que o mérito do pedido de suspensão é restrito à demonstração do interesse público ameaçado, ou seja, à ordem, à saúde, à segurança e à economia públicas, vedada a consideração do interesse tutelado pela decisão que se pretende suspender.

Insuscetível de tutela jurisdicional condizente com a urgência que se revela nos casos concretos, uma medida judicial protetiva do meio ambiente pode permanecer longamente sem eficácia, de sorte que o dano pode já ter irreversivelmente ocorrido quando for ela finalmente executável. Violados assim os princípios da inafastabilidade da jurisdição, da efetividade da prestação jurisdicional e do desenvolvimento sustentável.

Nesse quadro, a alternativa que se mostra eficaz para compatibilizar a suspensão da segurança com a Constituição e com o dever do Estado de defender e preservar o meio ambiente é se exigir, no âmbito do processo de suspensão, a apreciação da magnitude e da relevância da lesão ao interesse ambiental reconhecida na medida deferida contra o Poder Público, em contraste com a ameaça à ordem econômica comprovada pelo requerente. Em outros termos, a alternativa implica condicionar o deferimento do pedido de suspensão à demonstração de que a ameaça à economia pública, além de grave, não é aceitável quando cotejada com a lesão ao interesse ambiental decorrente da suspensão da execução da medida judicial deferida contra o Poder Público.

A realização desse exercício de ponderação implica necessariamente a demonstração da racionalidade e da justificação da decisão, o que contribui para afastar de uma vez para sempre qualquer resquício da concepção de que a suspensão de segurança é ato de natureza administrativa, praticado pelo julgador no exercício de poder discricionário.

Em verdade, na ordem constitucional vigente, em que o ambiente ecologicamente equilibrado foi erigido a direito fundamental, justifica-se a sua inclusão como um dos interesses tutelados pela suspensão da segurança.

Noutro aspecto, ao se condicionar a suspensão da segurança à necessidade da demonstração da prevalência do interesse do Poder Público, aferível no caso concreto mediante ponderação com o interesse ambiental, a regra da ultratividade da decisão suspensiva torna-se insustentável. A decisão suspensiva 
passa a ter duplo pressuposto, sendo um deles extraído da decisão suspensa. Por conseguinte, substituída essa decisão, não pode subsistir a decisão que suspendeu seus efeitos.

A alteração na conformação da suspensão de segurança, além de adequar o instituto à Constituição e conferir efetividade à tutela ambiental, pode contribuir para o aperfeiçoamento do manejo da ação civil pública e para o aperfeiçoamento dos estudos de impactos ambientais exigidos para empreendimentos potencialmente causadores de significativa degradação ambiental.

\section{REFERÊNCIAS}

AVILA, Humberto. Teoria dos princípios. 13. ed. São Paulo: Malheiros, 2012.

BARCELOS, Ana Paula de. Ponderação, racionalidade e atividade jurisdicional. Rio de Janeiro: Renovar, 2005.

BARROSO, Luis Roberto. Curso de direito constitucional contemporâneo. 4. Ed. São Paulo: Saraiva, 2013.

BAStOS, Celso Ribeiro. Curso de direito econômico. São Paulo: Celso Bastos, 2003.

BEZERRA, Isabel Cecília de Oliveira. Suspensão de tutelas jurisdicionais contra o poder público. Belo Horizonte: Fórum, 2009.

BRANCO, Paulo Gustavo Gonet. Juízo de ponderação na jurisdição constitucional. São Paulo: Saraiva, 2009.

BUENO, Cássio Scarpinella. Mandado de segurança. São Paulo: Saraiva, 2008.

CARVAlHO FILHO, José dos Santos. Ação civil pública. 4. ed. Rio de Janeiro: Lumen Juris, 2004.

CINTRA, Antônio Carlos de Araújo; DINAMARCO, Cândido Rangel; GRINOVER, Ada Pelegrini. Teoria geral do processo. 24. ed. São Paulo: Malheiros, 2008. 
DERANI, Cristiane. Direito ambiental econômico. 3. ed. São Paulo: Saraiva, 2008.

FERRAZ, Sérgio. Mandado de segurança. 4. ed. São Paulo: Malheiros, 2006.

FIGUEIREDO, Lucia Valle. Mandado de segurança. São Paulo:

Malheiros, 1997.

HESSE, Konrad. Escritos de Derecho Constitucional. Traducción Pedro Cruz Villalon. Madrid: Centro de Estudios Constitutionales, 1992.

MACHADO, Paulo Afonso Leme. Direito ambiental brasileiro. 17. Ed. São Paulo: Malheiros, 2009.

MARINONI, Luiz Guilherme. A técnica processual e tutela de direitos. 3 ed. São Paulo : RT, 2010.

MENDES, Gilmar Ferreira. Curso de direito constitucional. 7. ed. São Paulo: Saraiva, 2012.

PEREIRA, Hélio do Valle. Manual da fazenda pública em juízo. Rio de Janeiro: Renovar, 2003.

ROCHA, Caio Cesar. Pedido de suspensão de decisões contra o poder público. São Paulo: Saraiva, 2012.

RODRIGUES, Marcelo Abelha. Suspensão de segurança. 3. Ed. São Paulo: Revista dos Tribunais, 2010.

SARLET, Ingo Wolfgang; FENSTERSEIFER, Tiago. Direito constitucional ambiental. 2. ed. São Paulo: Revista dos Tribunais, 2012.

SARMENTO, Daniel. O Neoconstitucionalismo no Brasil: riscos e possibilidades. In: (Org.). Filosofia e teoria constitucional contemporânea. Rio de Janeiro: Lumen Juris, 2009. 
SCARTEZINI, Jorge Tadeo Flaquer. Suspensão de segurança. São Paulo: Revista dos Tribunais, 2010.

SILVA, Ovídio A. Baptista. Teoria geral do processo civil. 6. ed. São Paulo: Revista dos Tribunais. 2011.

SILVA, Virgílio Afonso. Direitos fundamentais: conteúdo essencial, restrições e eficácia. 2. ed. São Paulo: Malheiros, 2010.

TAVARES, André Ramos. Direito constitucional econômico. 3. ed. Rio de Janeiro: Forense; São Paulo: Método, 2011.

TOMBINI, Carla Fernanda Leão Barcelos. Suspensão de segurança na visão dos tribunais superiores. Belo Horizonte, Forum, 2009.

VENTURI, Elton. Suspensão de liminares e sentença contrárias ao poder público. 2. Ed. São Paulo: Revista dos Tribunais, 2010.

Artigo recebido em: 11/02/2014 Aprovado para publicação em: 30/06/2014

Como citar: BELlinetTI, Luiz Fernando. LUIZÃO, José Mauro. Suspensão da execução de medidas judiciais deferidas para a tutela de interesses ambientais. Scientia Iuris, Londrina, v.18, n.1, p.91-114, jul.2014. DOI: $10.5433 / 2178-8189.2014 \mathrm{v} 18 \mathrm{n} 1 \mathrm{p} 91$. 